\title{
Argumentation in Training Courses - Form and Function
}

\author{
Gabriela CHEFNEUX \\ Transilvania University of Braşov, Romania \\ Faculty of Letters \\ gabriela.chefneux@unitbv.ro
}

\begin{abstract}
The paper starts from the assumption that argumentation is a basic feature of everyday interaction; interlocutors resort to it to minimize disagreement, to resolve disputes, or to align the audience to the speakers' point of view. In order to achieve this, speakers continually adjust themselves to their audience's reaction, who play a major part in the process. The paper aims to analyse the arguments used during the opening stage of a training course for life insurance agents, arguments brought by the manager of the company providing the course. It considers their uses, structure, and linguistic realization. In terms of structure, the arguments are analysed in respect of their constituents - data, claim, qualifier, warrant, backing, and rebuttal (Toulmin (2003), while their linguistic realization is investigated at various levels - words, sentences, speech acts, and figures of speech. Using the data recorded during the training course, it selects the arguments that are considered more relevant with a view to identifying their function, structure, and lexical realization.
\end{abstract}

Keywords: argument, function, structure, reconstruction, lexical realization

\section{Introduction}

The aim of the paper is to analyse the way argumentation is used in training courses for adults. Starting from several examples from a recorded training course, the analysis focuses on the way in which the manager in charge of the course uses argumentation during the introductory part in order to persuade the participants that they attend a high-quality course, which will succeed in providing the information they need in order to become successful life insurance sales agents. The paper starts with a theoretical introduction of argumentation, presents the structure of arguments, and then discusses the arguments used by the manager of the training agency in terms of their aim and linguistic realization. 
Argumentation is an area of persuasion, which can be defined as an essential feature of everyday communication, a pervasive phenomenon in almost all discourse types such as educational, political, advertising, etc. (RovențaFrumuşani 2000: 5). Persuasion is considered the main reason of an argument: "persuasion is the ultimate goal of, or primary reason for, an argument" (Arp, Barbone, and Bruce 2019: 9).

Persuasion includes areas such as demonstration, argumentation, seduction, propaganda, and manipulation, differentiated by intensity, purpose, and means. Thus, demonstration aims to prove a theory true or false, relies on actual knowledge, has an intrinsic value, and represents a closed system. Seduction (in Latin "leading astray"), or rhetoric, negotiates the distance between subjects in terms of their opinion, focuses on the linguistic means used to persuade, and establishes a more direct contact with the audience; manipulation involves an illicit element, as it tries to persuade the audience in an indirect way, while propaganda reaches the extreme by its attempt to achieve its purpose in a violent and completely biased way (Rovența-Frumuşani 2000: 12).

Argumentation aims to solve disputes, misunderstandings, or differences of opinion by reaching a common position (Rovența-Frumuşani 2000: 24). It adjusts itself to the particular topic, to the audience's level or understanding, and to the characteristics of the field. Nowadays, argumentation has permeated most communication areas being present in a variety of text types: legal, scientific, everyday conversation, education, etc. (Rovența-Frumuşani 2000).

Argumentative texts represent one of the three major text types alongside narrative and descriptive ones; these types can also combine - for example, the argumentative one can include a narrative sequencing of arguments as well as a descriptive component when it supports values.

According to ancient rhetoric, argumentation consists of five parts: invention (the topic of the argument), disposition (the layout of arguments, support by evidence or proof, conclusion of the argument by means of summarizing it or appealing to the audience's feelings of compassion and sympathy), elocution (the aesthetic dimension, considered in terms of grammatical accuracy and figures of speech), memory (committing the speech to memory), and action (the actual delivery of the speech) (Perelman and Olbrechts-Tyteca 2012).

Rovența-Frumuşani (2000: 29) states that the actual aim of argumentation is to produce an epistemic change, influencing the audience's opinions and attitudes, while Perelman and Olbrechts-Tyteca (2012) consider that argumentation is mainly characterized by its continuous adjustment to the audience, changing its content and form according to the listeners. Van Eemeren and Grootendorst (1983) analyse argumentation as the response generated by an anticipated or actual difference of opinion; they approach argumentative moves in a pragmadialectical manner, the dialectical dimension being provided by the fact that 
the discussion observes a code and is conducted from a critical perspective, which means that the difference of opinion is solved based on the merits of the exchange, while the pragmatic one accounts for the analysis of exchanges in context. Pragma-dialectics studies arguments as part of ordinary conversation, their aim being to minimize the disagreement between the two interlocutors (van Eemeren 2010: 33-34). The regulations governing the argumentative exchange vary according to the four stages of the debate, namely, the difference of opinion (related to the standpoints defended or attacked by the two protagonists), the procedure and material stage (related to the discussants' agreeing on the premises and rules for their discussion), the argumentative stage (related to advancing the arguments), and the outcome (where the initial standpoints can be upheld or retracted) (van Eemeren 2010: 11).

Van Emmeren (2010: 12) classifies the argumentative scheme into three categories, namely causal, symptomatic, and comparative, depending on the relation between the standpoint upheld and the reason advanced, and he distinguishes between multiple, coordinative, and subordinate arguments.

Like Perelman and Olbrechts-Tyteca, van Eemeren (2010: 109) also emphasizes the important part played by the audience, who has an active role in the argumentative situation. He actually classifies the audience according to several criteria: in terms of the interlocutors' intended audience (primary or secondary), the speakers' intended effect on the audience, the audience's presence (physical or not), and the audiences' interest in and commitment to the topic.

Toulmin (2003: 12) defines arguments as justifications or advances brought in support of assertions, and he identifies the following constituents of an argument: data, warrant, backing, claim, qualifier, and rebuttal. The data refer to the assertion made by the first party, whereas the claim is the conclusion reached by using the data. The warrant - explained as "the answer to the challenger's question 'How did you get there'” (Toulmin 2003: 90) - can be incidental or implicit. Depending on the strength of the data and warrant, the force of the conclusion can vary, as indicated by the use of modal qualifiers. The warrant itself relies on backing, namely assurances provided for the warrant, which can take the form of a quotation of an authority in the field, a classification, statistics, etc. Unlike the data, without which no argument can start, warrants and backings can remain implicit. Finally, the rebuttal, which represents the rejection of the conclusion, depends on the strength of the warrants and backings (Toulmin 2003: 96). Rottenberg and Haisty Winchell (2018) adopt a very similar approach to the structure of the argument.

In their seminal work, The New Rhetoric: A Treatise on Argumentation (2012), Perelman and Olbrechts-Tyteca divide arguments into quasi-logical arguments and arguments based on the structure of reality. The former ones are similar to formal arguments and appeal to logical structures (including contradiction, 
partial or total identity, part-whole relation, comparison, and probability), while the latter rely on sequence and connection (including cause and effect, means and aims, persons and their actions). The authors illustrate all these types of arguments with examples and mention the figures of speech used in order to construct them.

Rovența-Frumuşani (2000) approaches the linguistic realizations of argument alongside a continuum - from the lowest units, the words, to argumentative operators and patterns and strategies (cause, interrogation, etc.). The lexical level includes singular and plural $1^{\text {st }}$ and $2^{\text {nd }}$ personal pronouns and verbs (tense, aspect and mood as well as lexical units such as contradict, contest, object, support, maintain), all indicating the speaker's opinion. She comments on the types of sentences (interrogative, exclamatory, or negative) and argumentative connectors (further subclassified as co-oriented, anti-oriented, introductory, and conclusion-introducing) and briefly mentions figures of speech (epithets, metaphors, metonymy).

\section{Data}

The data used for the analysis come from a training course organized by an insurance company. (For transcribing conventions, see the Appendix.)

There are seventeen people present - fifteen trainees aged between twenty and sixty and two representatives of the training company -, Dragoş, the manager of the agency, and Bogdan, a regional trainer. The data analysed represent the beginning of the course; this is the first time the participants meet and the manager presents the course.

The entire introductory part has a highly argumentative character. It has two main claims. The first is that the course is good and the warrants brought in support of this claim are of a varied nature - the structure of the course, the information conveyed, and the trainers' professionalism. The second claim is that what matters more in the insurance selling activity is the personality of the agents - a claim supported by statistics and psychology.

There is no direct confrontation of views, and the two parties do not commit themselves to the positions of protagonist and antagonist. Dragoş assumes that the participants are interested in the course, as indicated by their attending it, but he believes that at this stage their belief that they have made the right choice should be strengthened.

The analysis of the arguments observes the following pattern: reconstruction of the argument according to Toulmin's model (data, claim, warrant, backing, rebuttal, and qualifier), structure (multiple, coordinative, and subordinate), linguistic choice, and function. 


\section{Data Analysis}

\section{Example 1}

Dragoş starts the course by greeting the participants and by stating that the course lasts five full days; he combines the course presentation with personal introductions, a natural way of starting a course but also a means of working together more effectively.

Dragoş: bună ziua\#începem de astăzi $\downarrow$ o perioadă de cinci zile $\downarrow$ de cursuri pline $\downarrow$ vom avea cursuri de bază în activitatea de consultant. sigur că pentru început ar trebui să ne prezentăm ... împreună să lucrăm la opțiunile de care aveți nevoie să discutăm despre produsele [nume organizație] $\downarrow$ despre paşii procesului de vânzare şi despre tehnici de vânzare înainte de a merge mai departe va trebui însă (încetul cu încetul) să ne prezentăm fiecare, da $\uparrow$ nume prenume $\downarrow$, dacă lucrați unde lucrați MICI informații despre dumneavoastră care credeți că sunt importante astfel încât să ne cunoaştem împreună unii cu alții şi să vă cunosc şi eu mai bine pentru o mai bună colaborare. Hai\# CINE începe. (Gheorghe, Măda, and Săftoiu 2009: 175) Dragoş: good morning\# today $\downarrow$ we start a five-day period $\downarrow$ of busy courses $\downarrow$ we will have fundamental courses for the consultancy activity. of course, for the beginning we should introduce ourselves ... to work together on the options you need to discuss about the products [name of organization] $\downarrow$ the stages of the selling process and about selling techniques but before going on we will have to (step by step) introduce ourselves, yes $\uparrow$ name, surname $\downarrow$, if you work where you work SOME personal information which you consider important so that we know each other and I know you better to work better together with you. Come on\# WHO starts. ${ }^{1}$

Dragos combines the professional and the personal side of the course, the latter being subordinated to the former; he mentions introductions according to participants' expectations, as the customary way of starting a course ("of course, for the beginning we should introduce ourselves"), but this personal side is presented as a means to a different purpose - that of providing an efficient course: "so that we know each other and I know you better to work better together with you". This is Dragoş's first allusion to the high quality of the course.

The data is that the course starts, and the claim is that it should be efficient. The warrant is that the participants and trainers all have a common purpose, and the backing is that the training team is professional and flexible, adjusting quickly to the participants' needs. The claim has no qualifier, and the backing and the

1 The translations are my own throughout the article. 
conclusion are not overtly expressed. In terms of structure, this is a combined type of argument as it brings together professional and personal aspects (as indicated by the use of "so" and "but").

Linguistically, the use of of course is actually a way to show that Dragoş takes into account the trainees' expectations, while the use of but, when speaking about the participants' having to introduce themselves, indicates that he considers these introductions as a means subordinate to a higher end - that of making the course as efficient as possible. The participants are expected to introduce themselves but as a preliminary stage to the course, the reason provided for their self-introduction being to cooperate better.

The purpose of this argument is to persuade the trainees of the high quality of the course.

\section{Example 2}

Dragoş's following argument aims to boost the participants' self-confidence by persuading them that the insurance sales profession is not difficult. In order to do that, the manager starts by stating that it is impossible to work without making any mistakes, a theory assumed as accepted by all people present - as indicated by the use of the question "correct?". He takes this idea to the absurd when he says that not to make mistakes means not working at all, a statement that generates laughter. Next, Dragoş moves to the main part of his argument: he starts by addressing the trainees as my dear ones, suggests that he speaks the truth - "INDEED" - and concludes that not making any mistakes means not talking. At this stage, he changes the direction and explains that being a successful insurance agent does not mean being a good speaker but a good listener as the clients are the ones who have to persuade themselves that they need the insurance. As such, the clients would disclose their expectations and wishes, while the insurance agents only have to do the little part that remains - namely, telling the clients what they want to hear. This statement runs counter to the participants' expectations, being rather unexpected. This very feature, unexpectedness, suggests that Dragoş and the team of trainers have a thorough understanding of the psychological aspects of the profession.

Dragoş: eu am învăţat de mult că numa cine nu munceşte nu greşeşte. corect?.... asta ar însemna că mai bine nu vindem asigurări...ei $\downarrow$ dragii mei într-ADEVĂR ca să nu greşeşti înseamnă să nu vorbeşti. şi-i corect. sau dacă vreți dacă vrei să ai succes în asigurări este important să asculți mensamesaju clientului. Pentru că EL este singuru care va putea să se conVINgă cu efort minim din partea ta el este singurul care va putea să exprime CE-şi doreşte şi să-şi argumenteze dorința. eu nu va trebui decât să-i spun restu. (Gheorghe, Măda, and Săftoiu 2009: 177) 
Dragoş: I learnt a long time ago that only people who do not work do not make mistakes. correct?... that would mean that we had better not sell insurances... well $\downarrow$ my dear, INDEED not to make mistakes means not to speak. and it is true. or if you want to be successful in insurance it is important to listen to the client's message. Because HE is the only one who can persuade himself with a minimum effort on your behalf, he is the only one who will be able to express WHAT he wants and justify his desire. I will only have to tell him the rest.

As far as the audience is concerned, Dragoş is talking to one of the trainees, but his argument is aimed at all of them - from "if you (all)" (he corrects himself) to "if you (one) want to be successful" - which shows that his introductory part of the course has been very carefully planned.

This argument starts from an assumption which may contradict the trainees' belief, namely that it is listening rather than speaking that makes good insurance agents. This also represents a reason why the participants can feel more relaxed as their work seems not to be too difficult. Thus, since the client is the only one who can persuade himself, selling life insurances involves a minimum amount of effort on the trainees' behalf, and the only thing they need to do is to tell the client the rest. So, words such as "the only one", "minimum effort on your behalf", and "I will only have to" point to the lower effort involved on the part of the salesmen.

Using Toulmin's structure, the data are that insurance salesmen are supposed to sell their products, and the claim is that they have to be very persuasive. The warrant is quite unexpected as it is the client who sells the insurance rather than the salesman, while the backing is provided by psychology. The rebuttal of the claim is that unless they are good listeners, not speakers, as they may have initially believed, the trainees will not be successful sales agents. The data, backing, conclusion, and rebuttal are overtly expressed, while the qualifier is not expressed at all. This is a coordinated argument of an adversative type as its first part is contradicted by the second one.

From a linguistic point of view, it includes many negations (four in the first part) which correlate with the unexpected character of the latter statement. The brief question - "correct?" - is used to attract the participants on Dragoş's side and to suggest that his knowledge of selling insurances is very accurate. By using the first person plural personal pronoun ("we"), Dragoş makes further attempts at winning participants to his side. Only is used twice: as a restrictive adverbial ("I will only have to tell him the rest") and as a restrictive adjective ("HE is the only one who can persuade himself"), both instances suggesting that the insurance agents' work is not too difficult.

The purpose of this argument is to persuade the trainees that the sales agent's profession is not difficult as they are not expected to work much. 


\section{Example 3}

The next argument brought by Dragoş aims to persuade the trainees that the course will meet their specific needs. He starts by saying that he should best clarify some things from the beginning, while many others will be explained later. The course will not turn the trainees into perfect professionals, but that is not because the course is not good but because the activity involves working with people who have all different personalities. Another argument is that it is difficult to master such a complex field as understanding people requires a long time. Dragoş continues by presenting the overall structure of the course and returns to his previous statement by saying once more that there are no magical solutions and therefore the trainers cannot provide them, the only realistic expectation being that the course will reduce the trainees' chances of making mistakes.

Dragoş: ATENȚIE. tot de la început $\downarrow$ şi acest lucru o să-l vedeți şi mai încolo $\downarrow$ dar este bine să delimităm nişte lucruri de la început. da? noi nu avem acum pretenția că prin acest curs să facem din dumneavoastră oameni care cunosc asigurările\# din toate ungherele şi toate posibilitățile. în primul rând nici noi nu le cunoaştem chiar atât de bine şi n-o să ajungem experți nici peste două sute de ani $\downarrow$ dacă vom trăi. Nu ai cum, pentru că fiecare client în parte este o altă personalitate o altă structură. CINE să-mi poată mie da o soluție general valabilă pentru câteva miliarde de clienți posibili pe globul acesta. NIMENI. şi-atunci eu va trebui să mă adaptez la fiecare..... atunci haideți să vedem despre ce vom vorbi pe parcursul cursului $\downarrow$ da $\uparrow$. .... \# de fapt cineva spunea orice ai învăța în acest curs sau ulterior cursului împreună cu managerii dumneavoastră nu vom avea niciodată\# pretenția că o să vă dea soluții magice $\downarrow$ dar cu certitudine o să vă micşoreze şansa de a greşi. (Gheorghe, Măda, and Săftoiu 2009: 183)

Dragoş: ATTENTION. still from the beginning $\downarrow$ and you will see it later too $\downarrow$ but it is good to define some things from the beginning. yes? now we do not claim that by means of this course we will turn you into people familiar with insurances\# from all perspectives and all possibilities. first of all, we do not know them that well ourselves and will not become experts even in two hundred years $\downarrow$ if we come to live that long. this is not possible. because each client is a different personality a different structure. WHO can give me a solution valid for a few billions of possible clients in this world? NOBODY. And then I will have to adjust to each ... then let's see what we'll be talking about during the course $\downarrow$ yes $\uparrow$. ... \# actually, somebody said that no matter what you learn during this course or after it together with your managers we will never\# claim that it will provide you with magical solutions $\downarrow$ but certainly it will reduce the possibility of your making mistakes. 
The data is that the course cannot be expected to prepare the trainees to become perfect professionals, and the claim is that it is a good course because it reduces their possibilities of making mistakes. The warrant is the complexity of the activity, which makes the trainers' task difficult, and the backing is of a psychological nature (there are billions of clients, each having a particular psychological structure), while the rebuttal is that the course will be successful on condition that the trainees have reasonable expectations. The warrant, backing, claim, and rebuttal are overtly expressed while the claim and qualifier are not.

This is a complex argument whose overall aim is to promote the course. It consists of multiple arguments; firstly, the profession is very complex and difficult to master and, secondly, the course will provide more information, and therefore the participants should not worry. Dragoş presents two perspectives - an unreal one, where magical solutions are expected, and the real one, in which the course helps the participants to limit their future professional mistakes.

The first argument is supported by two backings that justify why the course cannot provide all the necessary information: the trainers themselves are not perfect, and the type of activity is too wide - there are billions of clients, each having a distinct personality. The second argument is the presentation of the course structure, which points to its comprehensive content.

The claim of this complex argument is that the course is efficient, the rebuttal being that the trainees should not have unrealistic expectations; the warrants are that the course content is well planned and that the profession is difficult, the backing being provided by psychology and statistics ("billions of clients, each having a different psychological structure"). The warrant and the backing are overtly expressed, while the claim is covert and has no qualifier.

From a linguistic perspective, the use of numbers is combined with interrogative and negative sentences: "billions of people", which is a numerical fallacy as no salesman will have so many clients, and "two hundred years" is another fallacy as no person can live that long. Actually, the latter figure also suggests that no amount of time is sufficient for insurance agents to become perfect in their profession. Dragoş uses a very logical sequence of statements meant to present him as a highly logical person; after the first part of his argument, related to the professional difficulties, he moves on to the course structure, a shift linguistically indicated by "then": "I will have to adjust to each ... then let's see what we'll be talking about during the course". Dragoş resorts to questions in order to make the trainees accept his point of view, while the use of many negations - "we do not claim that", "we ourselves do not know them", "it is simply not possible, or "we will never say" - indicates that Dragos wants to present himself as a very honest and realistic person as well as a thoroughly prepared trainer as he expects no wonders and is aware of the complexity of the sales agent profession. The modalizer used ("not possible") is related to the difficulty of providing 
solutions. Dragoş also resorts to repetition in order to persuade the trainees that the profession is really complex: insurance agents are "people familiar with insurances\# from all perspectives and all possibilities".

The purpose of this argument is to persuade the trainees that the course is good if they have realistic expectations and consider the complexity of the job.

\section{Example 4}

The manager concludes the introductory part of the course by an argument aimed to motivate the trainees. He starts from their reasons of attending the course (financial, personal worth, professional development, etc.) and attempts to persuade them that all their dreams may come true by working with the insurance company. He further suggests that the only possible obstacle in achieving their dreams is their own lack of determination and supports his assertion by resorting to statistics and his personal experience.

Dragoş starts by stating that the trainees should write their reason for attending the course as statistics indicate that individuals who write down their objectives have a far higher chance of achieving them. In order to fulfil their aims, sales agents have to visualize their objective at least once per day. If they do that, they have a reasonable chance of becoming members of the millionaire's club. Dragoş describes these people, some of whom he has actually met, as having an extremely high income and at least twenty years' of experience in the insurance field.

Dragoş: eu vă rog să vă notați acest obiectiv $\downarrow$ pentru că dacă nu vi-l notați cu certitudine n-o să-l atingeți sau veți avea şanse mici să ajungeți la obiectiv pentru că statisticile arată că dintre cei care-ş̧i stabilesc obiective douăzeci la sută îşi scriu obiectivul şi obzeci la sută nu. Dintre cei obzeci la sută care NU-ŞI scriu obiectivul $\downarrow$ zero virgulă zero la sută reuşesc să şi-l atingă. nu-l mai ştiu $\downarrow$ pentru că-şi schimbă părerea. cei care au un obiectiv real şi-l scriu cei douăzeci la sută $\downarrow$ da $\uparrow$ dintre ei douăzeci la sută şi-l scriu într-o zonă în care zilnic îl vizualizează şi douăzeci la sută şi l-au scris pur şi simplu. din cei care şi-au scris obiectivul cinci la sută reuşesc din cei care şi l-au scris într-o zonă vizibilă astfel încât zilnic o dată cel puțin să-şi vizualizeze obiectivul obzecişicinci la sută reuşesc. (Gheorghe, Măda, and Săftoiu 2009: 183)

Dragoş: I ask you to put down this objective $\downarrow$ because if you don’t put it down you will certainly not reach it or you will have low chances of reaching the objective because statistics show that out of the ones who set their objectives twenty percent write the objective and eighty percent don't. out of the eighty percent who do NOT write their objective $\downarrow$ nought point nought percent manage to achieve it. They don't know it any more $\downarrow$ 
because they change their mind. the ones that have a real objective write it the twenty percent $\downarrow$ yes $\uparrow$ out of them twenty percent write it in a place which they see every day and twenty percent just write it. out of the ones that wrote their objective five percent succeed out of the ones who write it in a visible area so that they see their objective at least once a day eightyfive percent are successful.

Dragoş tries to persuade the participants that they can be successful salesmen by writing down their objective and placing it in a visible location. Thus, he implies that this is a main requirement for professional success, indirectly stating that professional success entirely depends on the trainees. Statistics is used in such a way that the trainees are led to believe that $85 \%$ of them succeed.

The data are that the participants want to be successful professionals, and the claim is that they have to remember their objective. The rebuttal is that they cannot be successful unless they write down their objective and look at it every day. The warrant is that they must see their objective every day, and the backing is statistics. The warrant, backing, and claim are overtly expressed, but the claim has no qualifier. This is a long but structurally simple argument.

The use of figures is very clever - it seems that professional success can be achieved if the objective is known, written down, and remembered every day. The numbers are presented in a very manipulative sequence - only twenty percent of the trainees write their objectives down, the remaining $80 \%$ having absolutely no chance of meeting their objective. Out of the twenty percent who have written it down, 10\% (a figure not clearly stated) display it in a very visible place, and out of the low number of those who wrote down their objectives $85 \%$ succeed. This is actually a very low figure, considering the fact that it represents $85 \%$ of the $5 \%$ of the initial number of sales agents starting their career.

Linguistically this argument includes many figures, a conditional clause ("if you don't put it [the objective] down you will certainly not reach it"), and repetition (the word objective is used seven times).

The purpose of this argument is to persuade the trainees that they will be successful in their profession by following very simple rules.

It is worth mentioning that the sequence of Dragoş's arguments moves from promises related to the quality of the course, through an apparently candid and honest presentation of the psychological difficulties of the profession, and ends with an argument that points out that professional success is only the trainees' responsibility. 


\section{Conclusions}

The entire opening part of the course can be analysed as an argumentative type of discourse. The manager aims to promote the course by resorting to a variety of arguments, all pointing indirectly to the high quality of the course: it meets the participants' expectations, has a good structure, and provides all the information needed. As selling life insurances is a very complex activity and involves working with many different people, participants are warned not to expect miracles and are encouraged to trust the trainers and the course as they are given a reasonable amount of information. Dragoş wants to be perceived as a very honest person, and he presents the difficulties that the participants might be confronted with but reassures them that they do not have to work very hard (it is normal that they make mistakes, their work is mainly listening, and they succeed if they write down their objectives). Finally, he resorts to the participants' reasons for attending the course in order to boost their motivation.

He uses a combination of simple, multiple, and complex arguments, all very carefully sequenced and planned. He appeals mainly to the participants' reason but sometimes to their feelings, too. Generally, his arguments have overt claims and warrants, the backings are sometimes expressed, but the claims are never qualified, which points to the manager's trying to hide reality.

His arguments are backed by statistics and psychology, and linguistically he resorts to many rhetorical questions, negative sentences, and repetition, aimed at making the participants agree with his standpoint.

The manager's arguments are all construed in order to persuade the participants that they are at the right course, and it depends entirely on them to become successful insurance agents.

\section{References}

Arp, Robert-Steven Barbone-Michael Bruce. 2019. Bad Arguments - 1000 of the Most Important Fallacies in Western Philosophy. Hoboken: Wiley Blackwell.

Ionescu-Ruxăndoiu, Liliana (ed.). 2002. Interacțiunea verbală în limba română actuală. Corpus (selectiv). Schiță de tipologie [Verbal Interaction in Current Romanian. (Selective) Corpus. A Typology Outline]. Bucharest: Editura Universității din Bucureşti.

Gheorghe, Mihaela-Stanca Măda-Răzvan Săftoiu (eds). 2009. Comunicarea la locul de muncă. Corpul de interacțiune verbală în mediul profesional [Workplace Communication. Corpus of Verbal Interaction in Professional Context]. Braşov: Editura Universității Transilvania din Braşov. 
Perelman, Chaïm-Lucie Olbrechts-Tyteca. 2012. Tratat de argumentare. Noua retorică [The New Rhetoric: A Treatise of Argumentation]. Trans. Aurelia Stoica. Iaşi: Editura Universității “Alexandru Ioan Cuza” Iaşi.

Rottenbers, Anette-Donna Haisty Winchell. 2018. The Structure of Argument. Boston and New York: Macmillan Learning.

Rovența-Frumuşani, Daniela. 2000. Argumentarea. Modele şi strategii

[Argumentation. Models and Strategies]. Bucharest: Editura BIC ALL.

Toulmin, Stephen. 2003 [1958]. The Uses of Argument. Cambridge: Cambridge University Press.

van Eemeren, Frans Hendrik. 2010. Strategic Maneuvering in Argumentative Discourse. Amsterdam and Philadelphia: John Benjamins Publishing Company. van Eemeren, Frans Hendrik-Rob Grootendorst. 1983. Speech Acts in Argumentative Discussions. Dordrecht: Foris Publications.

\section{Appendix}

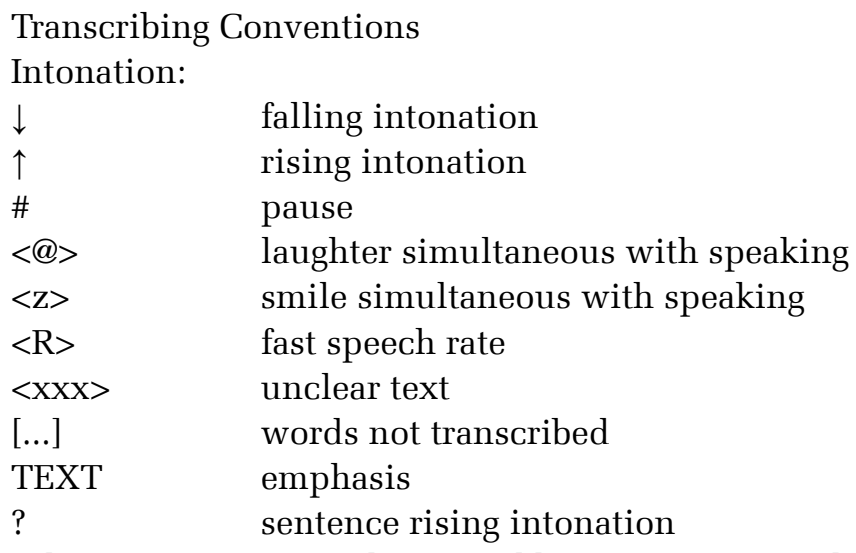

(The conventions are those used by Ionescu-Ruxăndoiu (2002). 